\title{
Laetitia Zecchini, Arun Kolatkar and Literary Modernism in India
}

\section{Manon Boukhroufa Trijaud}

\section{(2) OpenEdition \\ 1 Journals}

Electronic version

URL: https://journals.openedition.org/ces/5618

DOI: $10.4000 /$ ces. 5618

ISSN: 2534-6695

Publisher

SEPC (Société d'études des pays du Commonwealth)

\section{Printed version}

Date of publication: 1 September 2015

Number of pages: 111-112

ISSN: 2270-0633

\section{Electronic reference}

Manon Boukhroufa Trijaud, "Laetitia Zecchini, Arun Kolatkar and Literary Modernism in India",

Commonwealth Essays and Studies [Online], 38.1 | 2015, Online since 10 April 2021, connection on 10

July 2021. URL: http://journals.openedition.org/ces/5618; DOI: https://doi.org/10.4000/ces.5618

This text was automatically generated on 10 July 2021.

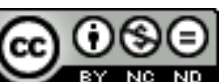

Commonwealth Essays and Studies is licensed under a Licence Creative Commons Attribution - Pas d'Utilisation Commerciale - Pas de Modification 4.0 International. 


\title{
Laetitia Zecchini, Arun Kolatkar and Literary Modernism in India
}

\author{
Manon Boukhroufa Trijaud
}

\section{REFERENCES}

Laetitia Zecchini. Arun Kolatkar and Literary Modernism in India. New Delhi: Bloomsbury Academic, 2014. 229 p. ISBN (hb): 9781441167507, £60. ISBN ebook: 9781472578327, $£ 59.99$

1 Laetitia Zecchini's Arun Kolatkar and Literary Modernism in India is the first monograph to be published on one of India's greatest contemporary poets. Though Arun Kolatkar remains a mystery outside India, he is one of the major figures of the Bombay poetry scene in the 1960s and 1970s. Kolatkar was both a successful advertiser and an undercover poet in the city who spent his life sitting in cafés, observing relentlessly the streets around him and looking for new ways to voice this post-independence India. He was a man who fled honours and distrusted publishers. Part of Zecchini's achievement is her use of yet unpublished material to illuminate Kolatkar's life and work.

2 This major critical study focuses on a particular figure in order to conjure up other poets who were part of the same creative turmoil. Arvind Krishna Mehrotra, Dilip Chitre or Adil Jussawalla were Kolatkar's friends and first audience. The author underlines the group's proper dynamic as she studies the importance of bilingualism and the extensive practice of translation. Indeed, most of them spoke and wrote in several languages. They used to publish, edit and review each other's work. They created their own publishing house, "Clearing House," and also animated a whole network of reviews and magazines. She refers to this golden age as "Bombay Bohemianism" or "Bombay Cosmopolitanism."

3 This cosmopolitanism is deeply connected to the "fantastic conglomeration of clashing realities" (35) of the port town. Kolatkar celebrates this composite aspect of reality and claims equally diverse sources of inspiration. Bombay poets found in Bhakti poetry 
their traditional inheritance. Zecchini makes some illuminating remarks on how claiming such a lineage is a subversive act. Bhakti poetry is an oral tradition whose concern is with ordinary and everyday life as opposed to the canons of an Indian poetry circumscribed to celebrating dharma - the Hindu concept of a harmonious hierarchised world. Therefore Bakhti poetry's place within tradition is one of marginality. Kolatkar and his friends dedicated part of their work to translating into English some of the greatest Bhakti poets, therefore preserving the diversity of tradition and confronting the univocity of the rising nationalist Hinduism.

4 Kolatkar's strength lies in his undeterred will to expose the complexity of reality. Through a multiplicity of examples, Zecchini focuses more closely on his technique and unique eye. She describes the poet's obsession for details and his ability to renew our vision of the world. He succeeds in "recording and defamiliarizing the ordinary" (91) as in his masterpiece Kala Ghoda Poems where a parking lot is transformed into a stage for his "street-theater." An unseen and unsuspected world unfolds on the city square. The pavement dwellers' presence is restored and is suffused with potential fiction. Zecchini's perfect knowledge of the collection owes much to the French translation she co-authored, with Pascal Aquien, in 2013.

5 She then considers the possibility of transnational modernism. For not only is Kolatkar's poetry inspired by Anglo-American modernists - he claims their influence as much as his Indian heritage - but it is also formally quite experimental. Zecchini had access to Kolatkar's wide collection of clippings, which reflects his multiple interests and his practice of accumulating elements to be reused and recycled in his poetry. Hence writing is a long process and "an art of assemblage," according to Kolatkar himself. The author draws some enlightening parallels with visual art works from this period such as surrealism and cubism. Kolatkar's poetry adjusts and combines different shapes, forms and structures. For the poet, "recycling is both a method of creation and a trope of Bombay" (118).

6 The work of assemblage and disturbance creates not only an aesthetic but also a political defamiliarization. Therefore, the last two chapters of the book are part of a whole entitled "The Politics of Kolatkar." Zecchini argues that Kolatkar's position is political because he accounts for reality in an improper, transgressive and subversive way. His poetry thrives on a chaotic reality, on slapstick comedy and wry humour. About his Jejuri, a poetical account of a country temple-town visit, he speaks of a "total debunking attitude towards worship" (153). The world he describes challenges the Brahmanic vision of society and "his forthrightness takes on an ethical and political significance" (160). Kolatkar was immensely concerned with political cleansing throughout history and witnessed the progressive rise of Hinduist nativism, an ideology that advocates purity in language, history and identity. But thanks to his "hospitable poetics" he restores India's real outsiders, the Dalits, to a body and a home, claiming that it is through the "improper" margins of society that regeneration can spring and particularly so, in a sick and amnesic city like Bombay.

7 Though the climate of fear and censorship created by India's contemporary cultural fundamentalism could account for the poet's and his current copyright holders' reluctance to publish, Arun Kolatkar's poetry is most certainly the key to "moving lines" and especially those of postcolonial studies of Indian literature whose focus has remained mainly on novels. The essence of his poetry is one of resistance towards any totalitarian speech or system, and a celebration of a multivocal history. Kolatkar is first 
and foremost a passionate story-teller who was fascinated by this oral craft for "no retelling is mere retelling; stories are inexhaustible" (176). This deeply researched book is a remarkable achievement and a first-hand source of plentiful information for readers interested in modern Indian poetry.

\section{AUTHORS}

\section{MANON BOUKHROUFA TRIJAUD}

Manon BOUKHROUFA TRIJAUD is currently a post-graduate student at Paris Sorbonne University; her PhD project is entitled "Bombay, city landscape, in Arun Kolatkar's and Nissim Ezekiel's poetry in English." 